Problem Based Leraning dalam Pembelajaran PAI dan Budi Pekerti...

\title{
PROBLEM-BASED LEARNING DALAM PEMBELAJARAN \\ PENDIDIKAN AGAMA ISLAM DAN BUDI PEKERTI \\ DI SMP AL-MUTTAQIN PATRANG JEMBER
}

\author{
Alek Efendi \\ Pendidikan Agama Islam Pascasarjana IAIN Jember \\ efendialek@gmail.com
}

\begin{abstract}
The learning process should be organized in an interactive, fun, so that students can participate actively. such learning can be realized by using a scientific approach. In its application can use Learning strategy. SMP Al-Muttaqin Patrang Jember has implemented of Problem Based Learning in the learning of Islamic Education and Character. The purpose of this research is to describe the Planning, Implementation and Assessment of Problem-Based Learning Strategy in learning Islamic Education and Character in SMP Al-Muttaqin Patrang Jember School Year 2017/2018. The results of the implementation of the Problem-Based Learning (PBL) strategy in the learning of Islamic Religion and Budi Pekerti at Al-Muttaqin Junior High School Patrang Jember showed that: 1) planning was carried out at the beginning of each school year; those involved in planning activities are Head master, students of the curriculum and subject teachers; the development of learning devices independently; all teachers submit learning device including PAI teachers and Characteristics. 2) The implementation of learning, the teacher presents a problem that must be observed by students. then students formulate questions and collect information, then students discuss it in groups to find solutions to problems and the results are presented in front. 3) Assessment of attitude competency is carried out by the teacher by observing students' behavior in the classroom or outside the classroom. knowledge competence with written test after the end of the learning material. Assessment of skills competencies conducted by the teacher during the learning process.
\end{abstract}

Kata Kunci: Problem-Based Learning, Pendidikan Agama Islam dan Budi Pekerti. 
Alek Efendi

\section{PENDAHULUAN}

Prinsip pembelajaran telah disesuaikan dengan Standar Kompetensi Lulusan dan Standar Isi dalam pendidikan. Beberapa prinsip-prinsip tersebut yiatu: dari peserta didik diberi tahu menuju peserta didik mencari tahu, dari guru sebagai satu-satunya sumber belajar menjadi belajar berbasis aneka sumber belajar, dari pendekatan tekstual menuju proses sebagai penguatan penggunaan pendekatan ilmiah. ${ }^{1}$

Pendekatan pembelajaran dapat merupakan titik tolak atau sudut pandang kita terhadap proses pembelajaran. Hal itu merujuk pada pandangan tentang terjadinya suatu proses yang sifatnya masih sangat umum, di dalamnya mewadahi, menginsiprasi, menguatkan, dan melatari metode pembelajaran dengan cakupan teoritis tertentu. Secara umum pendekatan pembelajaran dibagi mejadi dua, yaitu: (1) pendekatan pembelajaran yang berorientasi atau berpusat pada siswa (student centered approach) dan (2) pendekatan pembelajaran yang berorientasi atau berpusat pada guru (teacher centered approach). ${ }^{2}$

Kurikulum 2013 menggunakan Pendekatan Saintifik (scientific appoach) dalam prosses pembelajarannya. Pendekatan saintifik ini merupakan jenis dari pendekatan yang berpusat pada siswa (student centered approach) sebab pendekatan ini lebih memusatkan kegiatan aktif siswa dengan stimulus yang sebelumnya telah diberikan oleh guru agar siswa mampu menerapkan kelima tahapan pembelajaran saintifik tersebut dalam pembelajaran, lima tahapan tersebut terdiri atas kegiatan mengamati (untuk mengidentifikasi hal-hal yang ingin diketahui), menanya atau merumuskan pertanyaan, mengumpulkan informasi dengan satu atau lebih teknik, menalar atau mengasosiasi (menggunakan data atau informasi untuk menjawab pertanyaan dan menarik kesimpulan), dan mengomunikasikan. ${ }^{3}$

Penerapan pendekatan saintifik dapat diterapkan dengan beberapa stra-

\footnotetext{
${ }^{1}$ Kementerian Pendidikan dan Kebudayaan RI, Salinan Permendikbud. RI No. 22 Tahun 2016 tentang Standar Proses Pendidikan Dasar dan Menengah, ( Jakarta: Kemendikbud. RI, 2016), 2.

${ }^{2}$ Nana Sujana, Dasar-dasar Proses Belajar Mengajar, ( Bandung: Sinar Baru Algesindo, 2013),153.

${ }^{3}$ Kementerian Pendidikan dan Kebudayaan RI. Panduan Pembelajaran Untuk Sekolah Menengah Pertama. (Jakarta: Kemendikbud. RI, 2016). 29.
} 
tegi pembelajaran. Strategi pembelajaran yang sesuai dengan pendekatan pembelajaran saintifik yaitu pembelajaran berbasis inkuiri, pembelajaran penemuan (discovery learning), pembelajaran berbasis masalah (problem based learning), dan pembelajaran berbasis proyek (project-based leaming) dan strategi lain yang relevan. ${ }^{4}$

Strategi Pembelajaran Berabasis Masalah (problem-based learning) merupakan salah satu strategi yang relevan untuk mendudukung penerapan Pembelajaran yang efektif. dimana siswa akan lebih aktif dalam belajar, meningkatkan kemampuan mengkonstruksi pengetahuan, meningkatkan kemapuan dan ketraampilan pemecahan masalah, dan membiasakan untuk menerapakan pengetahuan sikap dan yang dimiliki untuk memecahkan masalah praktis dalam kehidupan sehari-hari.

Problem-Based Learning (PBL) sering disebut juga dengan Pembelajaran Berbasis Masalah. PBL merupakan suatu proses pembelajaran yang keterlibatan siswa dalam kegiatan pembelajaran lebih besar dalam memecahkan masalah. proses pemecahan masalah tersebut dengan menggunakan langkah-langkah ilmiah, sehingga siswa dapat mempelajari pengetahuan yang berhubungan dengan masalah yng disajjikan oleh guru, dalam prosesnya siswa berbekal pengetahuan yang dimilikin sebelunya, sehingga dari pengetahuan awal terbentuk pengetahuan yang baru. ${ }^{5}$

Ada tiga ciri utama dari PBL, yaitu: pertama, strategi PBL merupakan rangkaian aktivitas pembelajaran, artinya ada sejumlah kegiatan yang dilakukan yang akan dilakukan siswa, bukkan hanya mencatat, mendengar dan menghafal materi saja. Kedua, aktivitas pembelajaran tersebut diarahkan untuk menyelasaikan masalah, pembelajaran berbasis masalah menempatkan masalah sebagai kunci utama dalam aktivitas pembelajaran. Ketiga, pemecahan masalah dilakukan dengan menggunakan pendekatan ilmiah. Proses ini dilakukan secara sistematis dan empiris. ${ }^{6}$

Ada beberapa tahapan penting dalam strategi PBL. Yaitu klarifikasi

\footnotetext{
${ }^{4}$ Ridwan Abdullah Sani, Pembelajaran Saintifik untuk Implementasi Kurikulum 2013, (Jakarta: Bumi Aksara, 2014), 76.

${ }^{5}$ AgusAkhmadi, Pendekatan Saintifik: Model Pembelajaran Masa Depan, (Yogyakarta: Araska, 2015), 105.

${ }^{6}$ Wina Sanjaya. Strategi Pembelajaran Berorientasi Standar Pendidikan. (Jakarta: Kencana, 2011). 214.
} 
masalah, indentifikasi masalah, mengumpukan informasi, diskusi, mempresentasikan hasi penyelesaian masalah, dan refleksi. ${ }^{7}$ Strategi PBL didasarakan bahwa peserta didik akan belajar dengan baik apabila pembelajaran terkait masalah peristiwa yang terjadi di sekelilingnya. Pembelajaran ini menekankan pada daya pikir tinggi, mengumpulkan dan menganalisis data, memecahkan masalah-masalah tertentu. Dalam QS. Ali-Imran ayat 190-191, Allah SWT berfiman:

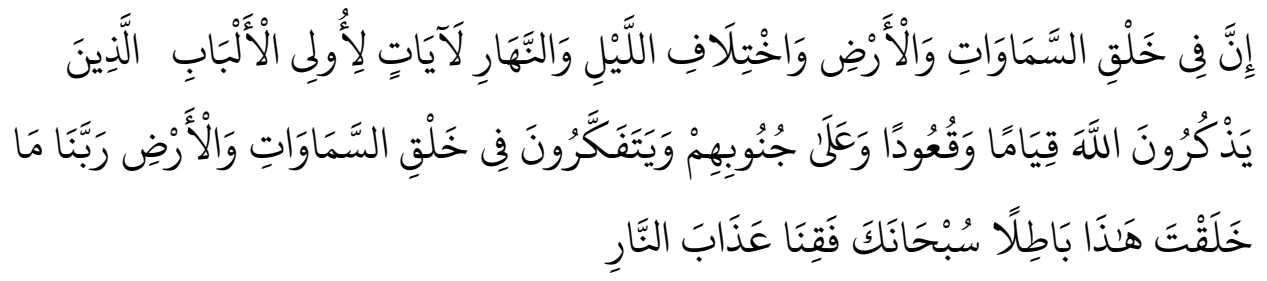

Artinya: "Sesungguhnya dalam penciptaan langit dan bumi, dan silih bergantinya malam dan siang terdapat tanda-tanda bagi orang-orang yang berakal. (yaitu) orang-orang yang mengingat Allah sambil berdiri atau duduk atou dalam keadan berbaring dan mereka memikirkan tentang penciptaan langit dan bumi (seraya berkata): "Ya Tuban Kami, Tiadalah Engkau menciptakan ini dengan sia-sia, Maha suci Engkau, Maka pelibaralah Kami dari siksa neraka".

Dalam ayat tersebut mengartikan bahwa manusia untuk senantiasa berfikir kritis dalam mencermati berbagai fenomena alam. dalam memahami alam sekitar dan memecahkan berbagai persoalan manusia harus mencurahkan segenap akal budinya. Proses mengamati fenomena dan persoalan dalam kehidupan sekitar akan menjadi strategi dalam melakukan sebuah proses pembelajaran agar mencapai pengetahuan yang diinginkan. Maka dalam konteks pendidikan dan pembelajaran diharapakan untuk seenantiasa melakukan kegiatan yang berkaitan dengan kegiatan berfikir mengenai persoalan disekitar.

Pada pembelajaran diperlukan sebuah strategi yang dapat mendorong siswa untuk melakukan proses pembelajaran secara aktif. Maka SMP AlMuttaqin Patrang Jember menggunakan strategi Problem-Based Learning. Khususnya pembelajaran PAI dan Budi Pekerti. Karena pembelajaran PAI

\footnotetext{
${ }^{7}$ Kementerian .Panduan Pembelajaran..., 54.

${ }^{8}$ Al-Qur'an, 3:190-191.
} 
dan Budi Pekerti masih sebagian besar materinya konseptual dan abstrak, sehingga pada menyebabkan para peserta didik cenderung malas untuk melakukan proses pembelajaran yang aktif dan interaktif. Oleh karena itu guru di tuntut untuk melakukan inivasi strategi pembelajaran agar siswa aktif dan kreatif dalam melakukan kegiatan pembelajaran. Oleh kare itu guru PAI dan Budi Pejerti menggunakan strategi Problem-Based Learning (PBL) dengan harapan guru mampu membuat siswa untuk belajar dengan belajara aktif dan kreatif.

Materi pembelajaran pada mata pelajaran pendidikan Agama Islam telah menggunakan strategi PBL, walaupun pada prosesnya masih banyak yang perlu disempunakan. Perumuskan perencanaan pembelajaran dikembangkan secara mandiri dengan berkoodinasi dengan wakil kepala sekolah bagian kurikulum, Hal ini menuntut guru untuk berkreatifitas secara mandiri. Pelaksanaan strategi PBL merupakan pembelajaran yang berpusat pada siswa. Pada pelaksanaanya guru hanya sebagai pembimbing dan memfasilitasi segala kegitan dan aktivitas pembelajaran, guru hanya sedikit mengarahkan bagaimana proses pembelajaran yang akan dilakukan, senlanjutnya siswa yang aktif untuk melakukan kegiatan tersebut. Dalam pelaksanaannya kadang beberapa siswa masih belum mengerti mengenai aktifitas yang di arahkan oleh guru, ini dikarenakan siswa masih belum terbiasa untuk melakukan aktifitas tersebut. Hal ini merupakan tantangan tersendiri bagi guru untuk terus belajar lagi tentang pelaksanaan strategi PBL. Namum hal itu tidak berlangsung lama, karena pembelajaran ini berbasis kegiatan maka siswa banyak yang semakin terbiasa dan antusias terhadap kegitan pembelajaran ini. ${ }^{10}$

Tulisan ini berusaha mengeksplorasi Problem-based Learning dalam pembelajaran Pendidikan Agama Islam dan Budi Pekerti pada aspek perencanaan, pelaksanaan serta kegiatan penilaiannya.

\section{METODE}

Penelitian ini Menggunakan pendekatan kualitatif deskriptif. Sedangkan jenis penelitian adalah Fenomenologi. Kehadiran peneliti dalam

\footnotetext{
${ }^{9}$ Naufal Abdillah, Wawancara, Jember, 27 Januari 2018.

${ }^{10}$ Naufal Abdillah, Wawancara, Jember, 20 Februari 2018
} 
penelitian ini bertindak sebagai perencana, pelaksana, penggali dan pengumpul data, penganalisis, penafsir data sekaligus sebagai pelapor data penelitian. Pemilihan informan dalam penelitian ini menggunakan teknik purposive. Informan yang dapat memenuhi tujuan dalam penelitian ini yaitu guru PAI dan budi pekerti serta peserta didik yang mengikuti pembelajaran PAI dan budi pekerti. Teknik pengumpulan data dilakukan dengan teknik wawancara, observasi, dan dokumentasi. Analisis data menggunakan analisis interaktif yang terdiri dari pengumpulan data (data collection), reduksi data (data reduction), penyajian data (data display), dan penarikan kesimpulan/verifikasi (conclusion drawing/veriffication). Uji keabsahan data menggunakan triangulasi sumber dan triangulasi metode.

\section{PEMBAHASAN}

Perencanaan strategi Problem-Based Learnig (PBL) dalam pembelajaran Pendidikan Agama Islam dan Budi Pekerti

Perencanaan adalah menyusun langkah-langkah yanag akan dilaksanakan untuk mencapai tujuan yang telah ditentukan. Perencanaan tersebut dapat disusun berdasarkan kebutuhan dalam jangka waktu tertentu sesuai dengan keinginan dan kebutuhan perencana. Perencanaan mengandung rangkaian-rangkaian keputusan yang luasdan penjelasanpenjelasan dari tujuan, penetuan kebijakan, penetuan program, penentuan metode-metode dan prosedur tertentu dan penetuan kegiatan berdasarkan jadwal sehari-hari. ${ }^{11}$

SMP Al-Muttaqin Patrang Jember perencanaan disusun mulai pada awal tahun pelajaran, dengan mengadakan rapat yang diikuti oleh kepala sekolah, wakil kepala sekolah, dan guru. pada tahap perencanaan dimulai dengan penyusunan Perangkat pelaksanaan pembelajaran (RPP) yang diinstruksikan kepada setiap guru mata pelajaran oleh kepala sekolah melalui rapat penyusunan Rencana Kerja dan kegiatan Sekolah. Rencana Pelaksanaan Pembelajaran (RPP) harus dibuat oleh setiap guru mata pelajaran dan di serahkan kepada kepala sekolah sebagai bukti dan periksa. Rencana Pelaksanaan tersebut diserahkan kepada kepala sekolah pada setiap

${ }^{11}$ Abdul Majid, Perencanaan Pembelajaran: Mengembangkan Standar Kompetensi Guru, (Bandung:remaja Rosda karya, 2013) , 15-16. 
materi pembelajaran atau setiap satu semester. Hal tersebut kepala sekolah mengetahui jika guru yang bersangkutan telah siap untuk melaksanakan proses pembelajaran dikelas bersama siswa.

Peran perencanaan pembelajaran sangat penting dalam memandu guru untuk melaksanakan tugas sebagai pendidik dalam melayani kebutuhan belajar siswa. Perencanaan pembelajaran juga dimaksudkan sebagai langkah awal sebelum pembelajaran berlangsung. Oleh karena itu diketahui berbagai manfaat dari perencanaan pembelajaran yang meliputi: Pertama, memberikan kejelasan dalam pencapaian kompetensi peserta didik. Dengan perencanaan yang baik maka akan memudahkan pelaksanaannya. Kedua, menigkatkan efesiensi dalam proses pelaksanaan. Adanya perencanaan akan memberikan gambaran tentang kebutuhan sumber daya yang diperlukan dalam mencapai kompetensi. Baik itu suberdaya manusia maupun sumberdaya non manusia. Dengan diketahuinya berbagai kebutuhan sumberdaya tersebut, maka proses pengadaan sumber daya dapat ditentukan terlebih dahulu.selain itu adanya perencanaan juga dapat menentukan proses yang tepat sehingga terhindar dari proses yang tidak jelas danberulangulang. ${ }^{12}$

Pengembangan RPP Pendidikan Agama Islam dan Budi Pekerti di SMP Al-Muttaqin Patrang Jember dilakukan oleh guru mata pelajaran dengan berkoodinasi dengan Wakil Kepala sekolah bagian Kurikulum. termasuk perumusan KI dan KD, Penentuan Kompetensi Inti dan Kompetensi Dasar guru menggunakan dokumen Kompetensi Inti dan Kompetensi Dasar yang telah disediakan oleh pemerintah yang telah ada disekolah, serta dalam buku paket pembelajaran.

Peraturan menteri pendidikan dan kebudayaan nomor 22 tahun 2016 menyatakan bahawa Setiap pendidik pada satuan pendidikan berkewajiban menyusun Rencana Pelaksanaan Pembelajaran (RPP) secara lengkap dan sistematis agar pembelajaran berlangsung secara aktif dan efektif. Rencana Pelaksanaan Pembelajaran (RPP) disusun berdasarkan Kompetensi Dasar (KD) atau subtema yang dilaksanakan satu kali pertemuan atau lebih. pene-

${ }^{12}$ Sugeng Listyo Prabowo, Perencanaan Pembelajaran: pada Bidang Studi, Bidang Studi Tematik, Muatan Lokal, Kecakapan Hidup, Bimbingan dan Konseling, (Malang: UINMaliki Press, 2010), 4. 


\section{Alek Efendi}

tuan Indikator Pencapaian Pembelajaran dan Tujuan Pembeajaran juga di susun berdasarkan Kompetensi Dasar (KD). ${ }^{13}$

Guru Pendidikan Agama Islama dan Budi Pekerti di SMP Al-Muttaqin Patrang Jember dalam mengembangkan Materi Pembelajaran serta penentuan sumber belajar berdasarkan buku paket. karena dalam buku paket tersebut dari kementerian pendidikan dan kebudayaan, maka maka materi sudah pembelajarannya sudah komprehensif. Buku tersebut juga dijadikan sebagai sumber utama dalam melakukan pembelajaran.

Pengembengan materi pembelajaran seharusnya menggunakan acauan kompetensi yang akan dicapai. Dalam pengembangan materi pembelajaran, hal-hal yang perlu dijadikan acuana adalah: ${ }^{14}$

1. Tingkat perkembangan

Tingkat perkembangan peserta didik menjadi penting untuk dijadikan pertimbangan sebagai pengembangan materi pembelajaran. karena ada beberapa perbedaan pada masing-masing tahap perkembangan anak.

2. Potensi peserta didik

Potensi peserta didik juga sangat mempengaruhi pengembangan materi. Hal ini terkait dengan intake. Sekolah yang memiliki intake yang tinggi tentu berbeda dengan intek yang rendah dalam kaitan pengemangan materi pembelajaran.

3. Relevansi dengan karakteristik daerah

Pendidikan harus mampu mengadopsi berbagai karakteristik unggul dan luhur dari masing-masing daerah.

4. Struktur keilmuan

Hal ini berkaitan dengan jenis ilmu dalm bidang studi materi pembelajaran,

5. Aktualitas, kedalaman dan keluasan materi

Aktualisasi bermakna sebagai tingkat keunggulan materi. Sedangkan kedalaman dan keluasan materi bermakna banyaknya ilmu pengetahuan yang harus dipelajari siswa.

${ }^{13}$ Kementerian Pendidikan dan Kebudayaan RI, Salinan Permendikbud. RI No. 22 Tahun 2016 tentang Standar Proses Pendidikan Dasar dan Menengah, ( Jakarta: Kemendikbud. RI, 2016), 6 .

${ }^{14}$ Sugeng Listyo, Perencanaan Pembelajaran..., 52-58 
Perumusan indikator kompetensi dapat menggunakan teori Benyamin S. Bloom yang dikembangkan berdasarkan tiga ranah yaitu ranah kognitif, afektif dan psikomotorik. Pengembangan indikator berakar pada setiap ranah tersebut, setiap ranah mempunyai kata kerja operasional yang mewakili masing-masing dari setiap ranah. Kata opersional tersebut dijadikan sebagai awalan kata kerja untuk menunjukkan ketercapaian pada kompetensi siswa. ${ }^{15}$

Setelah merumuskan Standar kompetensi dan indikator pencapaian pembelajaran guru Pendidikan Agama Islama dan Budi Pekerti di SMP AlMuttaqin Patrang Jember dalam memilih metode dan strategi pembelajaran. penentuan metode dan strategi pembelajaran ini tergantung kepada materi pembelajarannya.

Pemilihan metode dan Strategi pembelajaran yang tertuang dalam Rencana pelaksanaan Pembelajaran (RPP) berdasar pada beberapa pertimbangan.

1. Pertimbangan yang berhubungan dengan tujuan yang ingin dicapai Pertanyaan-pertanyaan yang dapat diajukan adalah:

a) Apakah tujuan pembelajaran yang ingin dicapai berkenaan dengan aspek kognitif, afektif atau psikomotor?

b) Bagaimana kompleksitas tujuan pembelajaran yang ingin dicapai, apakah tingkat tinggi atau rendah?

c) Apakah untuk mencapai tujuan itu memerlukan keterampilakademis?

2. Pertimbangan yang berhubungan dengan bahan atau materi pembelajaran.

Pertanyaan-pertanyaan yang dapat diajukan adalah:

a) Apakah materi pelajaran itu berupa fakta, konsep, hukum. atau teori tertentu?

b) Apakah untuk mempelajari materi pembelajaran itu memerlukan prasyarat tertentu atau tidak?

c) Apakah tersedia buku-buku sumber untuk mempelajari materi itu?

3. Pertimbangan dari sudut siswa.

Pertanyaan-pertanyaan yang dapat diajukan adalah:

${ }^{15}$ Sugeng Listyo, Perencanaan Pembelajaran..., 37. 
a) Apakah strategi pembelajaran sesuai dengan tingkat ke- matangan siswa?

b) Apakah strategi pembelajaran itu sesuai dengan minat, bakat, dan kondisi siswa?

c) Apakah strategi pembelajaran itu sesuai dengan gaya belajar siswa?

4. Pertimbangan-pertimbangan lainnya.

Pertanyaan-pertanyaan yang dapat diajukan adalah:

a) Apakah untuk mencapai tujuan hanya cukup dengan satu strategi saja?

b) Apakah strategi yang kita tetapkan dianggap satu-satunya strategi yang dapat digunakan?

c) Apakah strategi itu memiliki nilai efektivitas dan efisiensi?

Pertanyaan-pertanyaan di atas, merupakan bahan pertimbangan dalam menetapkan strategi yang ingin diterapkan. ${ }^{16}$

Rencana Pelaksanaan Pembelajaran (RPP) mata pelajaran Pendidikan Agama Islam dan Budi Pekerti di SMP Al-Muttaqin Patrang Jember menggunakan startegi Problem-Based Learnig (PBL) pada beberapa materi, 1) materi tentang Menghormati Orang Tua dan guru, dan Berempati kepada Sesama, 2) materi tentang Shalat Jamak dan Qasar, serta 3) materi tentang Akhlak terpuji (ikhlas sabar dan pemaaf).

Guru Pendidikan Agama Islama dan Budi Pekerti di SMP Al-Muttaqin Patrang Jember dalam menentukan media pembelajaran berdasarkan materi pembelajaran dan ketersediaan media pembelajaran. Sejalan dengan hal itu sesia dengan prinsip-prinsip media pembelajaran. Media pembelajaran digunakan dengan beberapa prinsip yang harus diperhatikan, diantaranya:

a. Media yang akan digunakan harus sesuai dan diarahkan untuk mencapai tujuan pembelajaran.

b. Madia yang dugunakan harus sesuai dengan materi pembelajaran, setiap materi pembelajaran memiliki kekhasan dan kekompleksan.

c. Media pembelajaran harus sesuai dengan minat, kebutuhan dan kondisi siswa.

d. Media yang akan digunakan harus memperhatikan efektifitas dan efisiensi.

${ }^{16}$ Wina sanjaya, Strategi Pembelajaran..., 130. 
e. Media yag digunakan harus sesuai dengan kemapuan guru dalam mengoprasikannya. ${ }^{17}$

Pelaksanaan strategi Problem-Based Learnig (PBL) dalam pembelajaran Pendidikan Agama Islam dan Budi Pekerti

Peningkatan mutu pendidikan adalah dengan mendorong pengembengan suatu proses pembelajaran pada sebuah lembaga pendidikan. Salah satu caranya adalah adalah dengan terus mengembangkan metode dan strategi dalam melaksanakan proses pembelajaran. Penggunaan metode pembelajaran yang inovatif akan semakin meningkatkan kualitas belajar siswa. Dalam konsep mutu yang lebih luas, mutu pendidikan mempunyai makna sebagai suatu kadar proses dan hasil pendidikan secara keseluruhan yang ditetapkan sesuai dengan pendekatan dan kriteria tertentu. ${ }^{18}$

Dengan kematangan kompetensi yang dimiliki oleh guru diharapkan guru mampu menemukan formula yang tepat dalam proses belajar mengajar. Keberhasilan proses belajar dipengaruhi oleh metode ataupun strategi yang digunakan oleh guru di dalam kegiatan belajar mengajar ketepatan dalam memilih metode menjadi kunci sukses dan tidaknya guru mengajar di dalam kelas. ${ }^{19}$

Guru mata pelajaran Pendidikan Agama Islam dan Budi Pekerti di SMP Al-Muttaqin Patrang Jember dalam melakukan proses pembelajaran menggunakan beberapa strategi pembelajaran, termasuk strategi ProblemBased Learnig (PBL). Penggunaan strategi tersebut diharapkan mampu memberikan daya rangsangan kepada peserta didik dalam menerima materi didalam kelas. Penggunaan strategi menjadi salah salah faktor penunjang keberhasilan pembelajaran.

Pendekatan saintifik ini merupakan jenis dari pendekatan yang berpusat pada siswa (student centered approach) sebab pendekatan ini lebih memusatkan kegiatan aktif siswa dengan stimulus yang sebelumnya telah diberikan oleh guru agar siswa mampu menerapkan kelima tahapan

\footnotetext{
${ }^{17}$ Wina Sanjaya, Strategi Pembelajaran..., 173-174.

18 Johan Huizinga. Homo Ludens. A Study of The Play Element in Culture (Boston: Beacon Press. 1955), 112.

${ }^{19}$ Wina sanjaya, Strategi Pembelajaran..., 13.
} 


\section{Alek Efendi}

pembelajaran saintifik tersebut dalam pembelajaran, lima tahapan tersebut terdiri atas kegiatan mengamati (untuk mengidentifikasi hal-hal yang ingin diketahui), menanya atau merumuskan pertanyaan, mengumpulkan informasi dengan satu atau lebih teknik, menalar atau mengasosiasi (menggunakan data atau informasi untuk menjawab pertanyaan dan menarik kesimpulan), dan mengomunikasikan. ${ }^{20}$

Pendekatan pembelajaran tersebut dapat diterapkan dengan beberapa strategi pembelajaran. Strategi pembelajaran yang sesuai dengan pendekatan tersebut adalah pembelajaran berbasis inkuiri, pembelajaran penemuan (discovery learning), pembelajaran berbasis masalah (problem based learning), dan pembelajaran berbasis proyek (project-based learning) dan strategi lain yang relevan. ${ }^{21}$

Problem-Based Learnig (PBL) merupakan suatu proses pembelajaran yang keterlibatan siswa dalam kegiatan pembelajaran lebih besar dalam memecahkan masalah. proses pemecahan masalah tersebut dengan menggunakan langkah-langkah ilmiah, sehingga siswa dapat mempelajari pengetahuan yang berhubungan dengan masalah yng disajjikan oleh guru, dalam prosesnya siswa berbekal pengetahuan yang dimilikin sebelunya, sehingga dari pengetahuan awal terbentuk pengetahuan yang baru. ${ }^{22}$

Penerapan strategi PBL pada mata pelajaran Agama Islam dan budi Pekerti di SMP Al-Muttaqin dilakukan sesuai dengan prosedur Perencanaan Pelaksanaan pembelajaran. bahwasanya langkah-langkah pembelajaran dilakukan melalui tahapan kegiatan pendahuluan, kegiatan inti, dan kegiatan penutup.

Pada pembelajaran Pendidikan Agama Islam dan budi pekerti, kegiatan pendahuluan dilakukan dengan membuka pelajaran dengan memberi salam dan berdoa bersama, serta membaca surat pendek bersama sebagai kebiasaan setiap hari, kemuadian memeriksa kehadiran siswa, dilanjutkan dengan menyampaiakan kegiatan pembelajaran yang akan dilakuakan.

Kegiatan Pembukaan atau disebut juga dengan kegiatan Pendahuluan, adalah suatu upaya untuk menciptakan suasana atau kondisi siap belajar

${ }^{20}$ Kementerian Pendidikan dan Kebudayaan RI. Panduan Pembelajaran Untuk Sekolah Menengah Pertama. (Jakarta: Kemendikbud. RI, 2016). 29.

${ }^{21}$ Ridwan Abdullah Sani, Pembelajaran Saintifik....,76.

${ }^{22}$ Agus, Pendekatan Saintifik...,105. 
sebelum memasuki tahap kegiatan inti pembelajaran. Abimanyu mengemukakan bahwa "kegiatan pendahuluan adalah kegiatan yang dilakukan oleh guru untuk menciptakan suasana siap mental dan menimbulkan perhatian siswa agar terpusat pada hal-hal yang akan dipelajari”. ${ }^{23}$

Pada kegiatan pendahuluan, guru: 1) menyiapkan peserta didik secara psikis dan fisik untuk mengikuti proses pembelajaran; 2) memberi motivasi belajar peserta didik secara kontekstual sesuai manfaat dan aplikasi materi ajar dalam kehidupan sehari-hari, dengan memberikan contoh dan perbandingan lokal, nasional dan internasional, serta disesuaikan dengan karakteristik dan jenjang peserta didik; 3) mengajukan pertanyaan-pertanyaan yang mengaitkan pengetahuan sebelumnya dengan materi yang akan dipelajari; 4) menjelaskan tujuan pembelajaran atau kompetensi dasar yang akan dicapai; dan 5) menyampaikan cakupan materi dan penjelasan uraian kegiatan sesuai silabus. ${ }^{24}$

Pada tahap kegiatan inti pembelajaran Pendidikan Agama Islam dan Budi Pekerti di SMP Al-Muttaqin Patrang Jember, menggunakan strategi Problem-Based Learnig (PBL). Langkah pembelajaran pertama guru menyajikan sebuah permasalahan dengan menayangkan sebuah film/video atau sebuah bacaan cerita pendek yang dibagikan kepada siswa.

Kegiatan mengamati adalah kegiatan belajaran yang dapat dilakukan peserta didik misalnya membaca, mendengar, menyimak, melihat (dengan atau tanpa alat). ${ }^{25}$ Pada kegiatan mengamati tersebut siswa mengidentifikasi terhadap fenomena yang telah di amati, pada dasarnya hal ini merupakan Pembelajaran Berbasis Masalah yaitu tahap klarifikasi masalah. pada tahap klarifikasi masalah guru menyajikan fenomena yang mengandung masalah yang sesuai dengan kompetensi dasar atau indikator. Dalam penyajiannya berupa gambar, teks, video, fenomena riil dan sebagainya, setelah itu siswa mengidentifikasi fenomena yang idtampilkan oleh guru guna menemukan masalah. ${ }^{26}$

${ }^{23}$ Abimanyu, Keterampilan Membuka dan Menutup Pelajaran, (Jakarta: P2LPTK Ditjen Dikti, 2004).11.

\footnotetext{
${ }^{24}$ Kementerian RI. Panduan ...,11.

${ }^{25}$ Musfiqon, Pendekatan..., 38

${ }^{26}$ Kementerian RI. Panduan ...,54.
} 
Pembelajaran pendidikan Agama Islam dan Budi Pekerti di SMP AlMuttaqin Patrang Jember adalah siswa membuat pertanyaan terakit dengan materi yang dijelaskan oleh guru dan disajikan oleh guru. Siswa bertanya tentang apa yang belum dipahami oleh siswa, pertanyaan tersebut ditanyakan langsung oleh siswa dengan mengacungkan tangan kepada guru. Pada kesempatan yang lain guru menyruh menulis pertanyaan tersebut dalam bukunya, kemudian siswa ditugaskan untuk mencari sendiri jawaban dari pertanyaan yang telah dibuat dengan cara mencari informasi di dalam buku pembalajaran siswa. Dalam kesempatan lain juga guru menugaskan siswa Siswa mencari informasi dan jawaban pertanyaan tersebut di internet sebagai tugas pekerjaan rumah.

Pada tahap tersebut merupakan kegiatan Menanya, pada kegiatan Menanya siswa merumuskan pertanyaan terkait dengan topik dan materi yang akan dipelajari. Guru membuka kesempatan secara luas kepada peserta didik untuk bertanya mengenai apa yang sudah dilihat, disimak, dibaca atau dilihat. Guru perlu membimbing peserta didik untuk dapat mengajukan pertanyaan. Semakin terlatih dalam bertanya maka rasa ingin tahu semakin dapat dikembangkan. Pertanyaan tersebut menjadi dasar untuk mencari informasi yang lebih lanjut dan beragam dari sumber yang ditentukan guru sampai yang ditentukan peserta didik, dari sumber yang tunggal sampai sumber yang beragam. ${ }^{27}$ Sedangkan pada Problem-Based Learnig (PBL) merupakan kegiatan Murumuskan Masalah dan Brainstorming. kegiatan ini siswa mendapat deskripsi masalah, apa yang diketahui, apa yang perlu diketahui, apa saja yang perlu dilakukan untuk penyelesaian masalah dengan merumuskan pertanyaan-pertanyaan. ${ }^{28}$ Selanjutnya dalam upaya penyelesaian masalah siswa melakukan pencarian informasi dan pengumpulan inforamsi. Hal ini dilakukan untuk menemukan sebuah solusi atas permasalahan yang telah dirumuskan. ${ }^{29}$ Pertanyaan terebut menjadi dasar untuk mencari informasi yang lebih lanjut dari sumber yang ditentukan guru sampai yang ditentukan peserta didik. Kegiatan ini dilakukan dengan menggali dan mengumpulkan informasi dari berbagai sumber melalui berbagai cara. Maka peserta didik

\footnotetext{
${ }^{27}$ Daryanto, Pendekatan Pembelajaran...,64.

${ }^{28}$ Sani, Pembelajaran Saintifik ...,58.

${ }^{29}$ Sani, Pembelajaran Saintifik ...,63.
} 
dapat membaca buku yang lebih banyak, memperhatikan fenomena atau objek yang lebih diteliti, atau bahkan melakukan eksperimen. Dari kegiatan tersebut terkumpul sejumlah informasi. Siswa juga dapat mengumpulkan informasi atau data dengan satu atau lebih teknik yang sesuai, misalnya eksperimen, pengamatan, wawancara, survei, dan membaca dokumendokumen. ${ }^{30}$

Pada pembelajaran Pendidikan Agama Islam dan Budi Pekerti di SMP AL-Muttaqin Patrang Jember, Siswa melakukan kegiatan diskusi secara kelompok untuk solusi pemecahan permasalahan terkait permasalahan awal yang disajikan oleh guru dan telah dirumuskan oleh siswa. diskusi dilakukan untuk menjawab pertanyaan sebagai penyelesaian masalah dan menyusun tugas yang nantinya akan dipresentasikan.

Diskusi merupakan kegiatan menalar atau mengasosiasi. Istilah mengasosiasi dalam kerangka proses pembelajaran dengan pendekatan ilmiah untuk mengembangkan bahwa guru dan peserta didik merupakan pelaku aktif. Titik tekannya tentu dalam banyak hal dan situasi peserta didik harus lebih aktif daripada guru. Penalaran adalah proses berfikir yang logis dan sistematis atas fakta-fakta empiris yang dapat diobservasi untuk memperoleh simpulan berupa pengetahuan. Penalaran dimaksud merupakan penalaran ilmiah, meski penakaran nonilmiah tidak selalu tidak bermanfaat. ${ }^{31}$ Tahap ini siswa menggunakan informasi atau data yang sudah dikumpulkan untuk menjawab pertanyaan yang telah dirumuskan dan menarik kesimpulan. Setelah itu siswa menentukan solusi pemecahan masalah, selanjutnya menyusun hasil laporan hasil diskusi penyelesaian maslah.

Pembelajaran Pendidikan Agama Islam dan Budi Pekerti di SMP AlMuttaqin Patrang Jember melakukan presentasi dalam rangka melaporkan hasil diskusi yang telah dilakukan, bahan presentais disusun di sebuah kertas Manila putih, kemudian dipresentasikan dengan ditempelkan di depan papan tulis, presentasi dilakuakoleh perwakilan dari masing-masing kelompok.

Presentasi merupakan kegiatan Mengomunikasikan. Kegiatan ini yaitu menceritakan apa yang ditemukan dalam kegiatan mencari informasi,

\footnotetext{
${ }^{30}$ Permendikbud RI. Panduan Pembelajaran ,33.

${ }^{31}$ Hosnan, Pendekatan Saintifik...,67.
} 


\section{Alek Efendi}

mengasosiasikan dan menemukan pola. Hasil tersebut disampikan di kelas dan dinilai oleh guru sebagai hasil belajar peserta didik atau kelompok peserta didik tersebut. ${ }^{32}$

Pada strategi Problem-Based Learnig (PBL) kegiatan presentasi merupakan Laporan hasil diskusi tentang solusi ynag dikemukakan untuk menyelsaikan masalah di presentasikan di depan kelas. Dalam presentasi tersbut bisa dilakukan diskusi kelas untuk mereviu, menganalisis, dan mengevasluasi terhadap pemecahan masalah yang ditawarkan serta alasannya, yang kemudian selanjunya siswa bisa melakukan perbaikan berdasarkan hasil diskusi kelas tersebut. ${ }^{33}$

Kegiatan penutup pada pembelajaran Pendidikan Agama Islam dan Budi Pekerti di SMP Al-Muttaqin Patrang jember guru merefleksi rangkaian kegiatan pembelajaran dan hasil yang diperoleh. Guru menginformasikan kegiatan pembelajaran pada pertemuan yang akan datang, setelah itu guru mengajak siswa untuk berdoa bersama sebagai akhir dari pembelajaran dan guru mengucapakan salam.

Menurut Ahmad Sabri menutup pelajaran merupakan kegiatan yang dilakukan oleh guru untuk mengakhiri kegiatan inti pembelajaran. Menutup pelajaran juga dapat diartikan aktivitas menjelang akhir pelajaran atau ahir setiap penggal kegiatan dengan maksud agar siswa memperoleh gambaran yang utuh tentang pokok materi. ${ }^{34}$

Dalam Permendikbud Nomor 22 tahun 2016 dinyatakan bahwa dalam kegiatan penutup, guru bersama peserta didik baik secara individual maupun kelompok melakukan refleksi untuk mengevaluasi: a) refleksi rangkaian aktivitas pembelajaran dan hasil-hasil yang diperoleh untuk selanjutnya secara bersama menemukan manfaat langsung maupun tidak langsung dari hasil pembelajaran yang telah berlangsung; b) memberikan umpan balik terhadap proses dan hasil pembelajaran;c) melakukan kegiatan tindak lanjut dalam bentuk pemberian tugas, baik tugas individual maupun kelompok; dan d) menginformasikan rencana kegiatan pembelajaran untuk

${ }^{32}$ Kementerian, Panduan Pembelajaran ..., 33.

${ }^{33}$ Kemdikbud RI. Panduan Pembelajaran...,54-56.

${ }^{34}$ Ahmad Sabri, Strategi Belajar Mengajar Micro Teaching,(Ciputat: Quantum Teaching, 2007), 99. 
Problem Based Leraning dalam Pembelajaran PAI dan Budi Pekerti...

pertemuan berikutnya. ${ }^{35}$

Komponen menutup pelajaran, antara lain:

1. Meninjau kembali (meriviu)

Meninjau kembali pada dasarnya adalah upaya untuk melaksanakan kilas balik terhadap penguasaan siswa dari pokok materi yang telah dipelajari.

2. Menilai (mengevaluasi)

Kegiatan menutup pembelajaran dapat dilakukan dengan jalan memberikan penilaian atau evaluasi atas materi yang telah disampaikan dengan tujuan untuk mengetahui sejauhmana penguasaan materi yang telah dilakukan.

3. Menyimpulkan

Kesimpulan adalah rumusan pokok-pokok pikiran atau kristalisasi terhadap sesuatu yang dibahas. Dengan mengajukan kesimpulan, maka guru melakukan kegiatan penutupan pembelajaran karena dengan kesimpulan merupakan akhir dari suatu proses penyelesaian masalah sebelum adanya masalah baru.

4. Tindak lanjut

Tindak lanjut merupakan kegiatan yang harus dilakukan peserta didik setelah pembelajaran dilakukan. Kegiatan tindak lanjut perlu diberikan oleh guru agar terjadi pemantapan pada diri peserta didik terhadap pencapaian tujuan pembelajaran yang telah dirumuskan. ${ }^{36}$

\section{Penilaian strategi Problem-Based Learnig (PBL) dalam pembelajaran} Pendidikan Agama Islam dan Budi Pekerti

Penilaian merupakan kegiatan mengumpulkan informasi belajar peserta didik. Kegiatan tersebut diperoleh dari berbagai jenis tagihan dalam pembelajaran, kemudian informasi tersebut diolah untuk dinilai perkembangannya. Secara umum dalam menilai sebuah hasil pembelajaran maupun menilai pada proses pemebelajaran berdasar pada kompetensi atau

${ }^{35}$ Kementerian Pendidikan dan Kebudayaan RI, Salinan Permendikbud. RI No. 22 Tahun 2016 tentang Standar Proses Pendidikan Dasar dan Menengah, ( Jakarta: Kemendikbud. RI, 2016),12.

${ }^{36}$ Dadang Sukirman dan Mamad Kasmad, Pembelajaran Mikro, (Bandung: UPI Press, 2006),151. 


\section{Alek Efendi}

masing masing aspek. Aspek tersebut terdiri dari aspek sikap, sikap sosial maupun spiritual, aspek pengetahuan dan aspek keterampilan.

Penilaian sikap siswa dengan mengamati perilaku siswa dalam kelas maupun diluar kelas serta dari laporan para siswa dan guru dan mencatatnya dalam instrumen penilaian. Salah satu hal yang penting untuk dinilai selain pengetahuan siswa dan keterampialn siswa adalah sikap. Untuk menilai hasil belajar berupa sikap adalah salahsatunya menggunakan isnstrumen observasi, Observasi merupakan proses pengamatan langsung dan pencatatan sistematis mengenai prilaku dna proses kerja peserta didik baik secara individu maupun kelompokuntuk mencapai tujuan tertentu. Observasi merupakan teknik penilaian yang dilakukan secara berkesinambungan dengan menggunakan indra, baik secara langsung maupun tidak langsung dengan menggunakan pedoman atau lembar observasi yang berisi sejumlah indikator perilaku atau aspek yang diamati. ${ }^{37}$ Perilaku seseorang pada umumnya menunjukan kecenderungan seseorang dalam sesuatu hal. Oleh sebab itu, pendidik dapat melakukan observasi terhadap peserta didiknya. Hasil observasi dapat dijadikan sebagai umpan balik dalam pembinaan terhadap peserta didik. Pengamatan atau observasi perilaku peserta didik dalam pembelajaran dapat dilakuakan dengan menggunakan alat lembar pengamatan atau observasi. ${ }^{38}$

Keunggulan penilaian kompetensi sikap spiritual dan sikap sosial dengan menggunakan instrumen observasi atau pengamatan yaitu; data yang diperoleh relatif objektif, karena diperoleh melalui pengamatan langsung dari guru, hubungan guru dan peserta didik lebih dekat, karena dalam pengamatan tentu guru harus berinteraksi dengan peserta didik dan guru memiliki keleluasan dalam menentukan aspek-aspek apa saja yang mau diamati dalam pembelajaran, sehingga guru dapat mengumpulkan segala invormasi yang berkaitan dengan kompetensi sikap spiritual dan sikap sosial secara komperhensif. Sedangkan kelemahan penilaian kompetensi sikap spiritual dan sikap sosial dengan menggunakan instrumen observasi atau pengamatan yaitu; pencatatan data sangat tergantung pada kecermatan guru

${ }^{37}$ Salim Wazdy dan Suyitman, Memahami Kurikulum 2013; Panduan Praktis untuk Guru Pendidikan Agama Islam dan Budi Pekerti (Kebumen: IAINU Kebumen, 2014),149.

${ }^{38}$ Latifatul Mida Muzamiroh, Kupas Tuntas Kurikulum 2013 (Kelebihan dan KekuranganKurikulum 2013), (Kota Pena, 2013), 33. 
dalam pengamatan dan daya ingatan dari observer (guru) dan memerlukan kecermatan dan keterampilan dari guru dalam melakuakan observasi, karena kalau tidak cermat data yang diperoleh hasil manipulasi atau dibuat-buat dari subjek yang diobservasi. Dan ini berimplikasi terhadap objektivitas data hasil pengamatan. ${ }^{39}$

Adapun teknis observasi penilaian autentik ranah sikap dapat menempuh langkah-langkah sebagai berikut:

1) Guru mencatat seluruh sikap atau nilai karakter yang akan dikembangkan seperti jujur, disiplin, tanggung jawab, santun, peduli, dan percaya diri dalam berinteraksi dengan keluarga, teman, guru, dan tetangganya serta cinta tanah air.

2) Kemudian sikap-sikap tersebut dilakukan secara tidak langsung melalui aktivitas pembelajaran yang dilakukan, guru diharapkan dapat melakukan penilaian secara langsung atas ketercapaian nilai karakter tertentu pada diri siswa.

3) Mengingat kendala yang ada, terutama ketersediaan waktu dan banyaknya jumlah peserta didik, maka dalam satu semester, guru dapat menentukan dua atau tiga nilai karakter/sikap yang akan dikembangkan dan dinilai secara langsung. Jenis karakter yang akan dikembangkan, hendaknya menjadi keputusan sekolah meskipun tidak tertutup kemungkinan, dalam satu kelas ada tambahan satu atau dua nilai karakter lain, sesuai dengan kebutuhan di kelas tersedia. Misalkan dalam satu semester ini, sikap/karakter yang akan dikembangkan adalah disiplin, kerja sama, dan percaya diri. ${ }^{40}$

\section{SIMPULAN DAN SARAN}

Simpulan

Perencanaan strategi PBL dalam pembelajaran Pendidikan Agama Islam dan Budi Pekerti di SMP Al-Muttaqin Patrang Jember guru mengembangkan RPP PAI dan Budi Pekerti secara mandiri dan berkoodinasi dengan Wakil Kepala sekolah bagian kurikulum. Pengembangan RPP meliputi: perumusan KI dan KD, Tujuan

\footnotetext{
${ }^{39}$ Kunandar, Penilaian Autentik. . . ., 122.

${ }^{40}$ Kunandar, Penilaian Autentik. . . ., 122.
} 


\section{Alek Efendi}

pembelajaran, Materi Pembelajaran, Strategi dan Metode Pembelajaran, sumber belajar, serta penilaian pembelajaran.

Pelaksanaan pembelajaran meliputi kegiatan pendahuluan, inti dan penutup. Kegiatan pendahuluan meliputi mengucap salam dan berdoa bersama, memeriksa kehadiran siswa, dan menyampaiakan rencana kegiatan pembelajaran. Kegiatan inti Pembelajaran pembelajaaran dimulai dengan mengamati sebuah tayangan video (Proyektor) dan juga bacaan yang berisi tentang suatu cerita yang mengandung permasalahan. Setelah identifikasi masalah siswa merumusakan pertanyaan dan mencari informasi di dalam buku pembalajaran siswa, kegiatan tersebut dilakukan dalam kelompok diskusi. diskusi juga dilakukan untuk menyusun tugas sebagai bahan presentasi didepan kelas, setelah diskusi selesai maka hasil diskusi dipresentasikan oleh masing-masing kelompok. Kegiatan penutup guru merefleksi rangkaian kegiatan pembelajaran dan hasil yang diperoleh. Guru menginformasikan kegiatan pembelajaran pada pertemuan yang akan datang, setelah itu guru mengajak siswa untuk berdoa bersama sebagai akhir dari pembelajaran dan guru mengucapakan salam.

Penilaian praktek menggunakan instrumen penilaian unjuk kerja. Sedangkan penilaian sikap menggunakan instrumen Observasi yang dilakukan didalam kelas maupun diluar kelas. Pada aspek pengetahuan penilaian dilakukan dengan instrumen tes. Pada aspek keterampilan Penilaian dilakukan ketika kegiatan pembelajaran berlangsung menggunakan teknik penilaian non-tes dengan instrumen observasi Skala Penilaian (rating scale).

\section{Saran}

Kepala madrasah harus terus mendorong guru untuk terus mengembangkan pembelajaran. dari segi perencanaan, pelaksanaan pembelajaran termasuk dalam mengembangkan strategi pembelajaran, dan evaluasi pembelajaran. serta terus mengontrol kegiatan pembelajaran yang berlangsung dikelas. pengwasan perlu dilakaukan supaya guru termotivasi untuk melaksanakan kegiatan pembelajaran secara profesional. Kepada Guru dalam memperbaiki dan meningkatkan profesionalisme dalam proses belajar mengajar hendaknya para guru lebih aktif dan kreatif dalam memilih me- 
Problem Based Leraning dalam Pembelajaran PAI dan Budi Pekerti...

tode yang tepat untuk proses pembelajaran siswa.

\section{DAFTAR PUSTAKA}

Kementerian Pendidikan dan Kebudayaan RI, Salinan Permendikbud. RI No. 22 Tahun 2016 tentang Standar Proses Pendidikan Dasar dan Menengah, ( Jakarta: Kemendikbud. RI, 2016)

Nana Sujana, Dasar-dasar Proses Belajar Mengajar, ( Bandung: Sinar Baru Algesindo, 2013)

Kementerian Pendidikan dan Kebudayaan RI. Panduan Pembelajaran Untuk Sekolah Menengah Pertama. (Jakarta: Kemendikbud. RI, 2016). 29.

Ridwan Abdullah Sani, Pembelajaran Saintifik untuk Implementasi Kurikulum 2013, (Jakarta: Bumi Aksara, 2014)

AgusAkhmadi, Pendekatan Saintifik: Model Pembelajaran Masa Depan, (Yogyakarta: Araska, 2015)

Wina Sanjaya. Strategi Pembelajaran Berorientasi Standar Pendidikan. (Jakarta: Kencana, 2011)

Abdul Majid, Perencanaan Pembelajaran: Mengembangkan Standar Kompetensi Guru, (Bandung:remaja Rosda karya, 2013)

Sugeng Listyo Prabowo, Perencanaan Pembelajaran: pada Bidang Studi, Bidang Studi Tematik, Muatan Lokal, Kecakapan Hidup, Bimbingan dan Konseling, (Malang: UIN-Maliki Press, 2010)

Kementerian Pendidikan dan Kebudayaan RI, Salinan Permendikbud. RI No. 22 Tahun 2016 tentang Standar Proses Pendidikan Dasar dan Menengah, ( Jakarta: Kemendikbud. RI, 2016)

Johan Huizinga. Homo Ludens. A Study of The Play Element in Culture (Boston: Beacon Press. 1955), 112.

Kementerian Pendidikan dan Kebudayaan RI. Panduan Pembelajaran Untuk Sekolah Menengah Pertama. (Jakarta: Kemendikbud. RI, 2016)

Abimanyu, Keterampilan Membuka dan Menutup Pelajaran, (Jakarta: P2LPTK Ditjen Dikti, 2004).11.

Ahmad Sabri, Strategi Belajar Mengajar Micro Teaching,(Ciputat: Quantum Teaching, 2007) 
Alek Efendi

Kementerian Pendidikan dan Kebudayaan RI, Salinan Permendikbud. RI No. 22 Tahun 2016 tentang Standar Proses Pendidikan Dasar dan Menengah, ( Jakarta: Kemendikbud. RI, 2016)Dadang Sukirman dan Mamad Kasmad, Pembelajaran Mikro, (Bandung: UPI Press, 2006)

Salim Wazdy dan Suyitman, Memahami Kurikulum 2013; Panduan Praktis untuk Gum Pendidikan Agama Islam dan Budi Pekerti (Kebumen: IAINU Kebumen, 2014)

Latifatul Mida Muzamiroh, Kupas Tuntas Kurikulum 2013 (Kelebihan dan KekuranganKurikulum 2013), (Kota Pena, 2013)

Imas Kurinasih dan Berlin Sani,Implementasi Kwikulum 2013: Konsep dan Penerapan. (Surabaya: Kata Pena, 2014)

Iif Khoiru Ahmadi dan Sofan Amri, Pengembangan dan Model Pembelajaran Tematik Integratif (Jakarta: Prestasi Pustaka, 2014)

Nyoman S. Degeng, Teori Pembelajaran 1 Taksonomi Variabel (Malang: Universitas Terbuka, 2009)

Kokom Komalasari, Pembelajaran Kontekstual: Konsep dan Aplikasi, (Bandung: PT Refika Aditama, 2013) 